\title{
STRENGTHENING YOUTH WELLBEING THROUGH GREEN SPACES: CASE STUDY OF A SMALL TOWN
}

\author{
Gintarė Vaznoniené ${ }^{1}$, Bernardas Vaznonis ${ }^{2}$ \\ ${ }^{1}$ Assoc. prof. dr., Vytautas Magnus University. Address: Universiteto g. 10, 53361 Akademija, Kaunas distr. \\ Lithuania, Phone number+370 37 752214,E-mail: gintare.vaznoniene@vdu.lt \\ ${ }^{2}$ Assoc. prof. dr., Vytautas Magnus University. Address: Universiteto g. 10, 53361 Akademija, Kaunas distr. \\ Lithuania.Phonenumber+370 37 752 277,E-mail: bernardas.vaznonis@vdu.lt
}

Received 1902 2020, Accepted 23062020

The article deals with the concept of green spaces as a part of green infrastructure by highlighting its benefit to wellbeing of the youth living in a small town. Properly maintained and equipped green spaces are positive elements of living environment which attracts youth to stay where they live and not to move to cities. The increasing interest in wellbeing issues in different territorial levels reveals the necessity to explore how youth wellbeing can be strengthened by using, being and acting in green spaces. The aim of the article is to analyse the importance of green spaces to youth wellbeing. The research question: in which ways can green spaces contribute to better wellbeing of youth? Case study and experts' interview methods were used to explore the formulated research question. The results of the research have demonstrated that green spaces promote youth wellbeing including personal development, physical functioning, emotional status, and have positive effects on their overall wellbeing. The results may serve as the groundwork for further researches of this kind and as the guidelines for local communities in small towns and other actors concerned with promotion of youth wellbeing.

Key words: youth, wellbeing, green spaces, small town, case study.

JEL kodai: J13, R11, Q56.

\section{Introduction}

The concept of green spaces is multidimensional and tends to vary in research according to the researchers' aims, activity, and fields of interest. A series of studies (Benedict, McMahon, 2006; Green infrastructure..., 2011; M'Ikiugu et al., 2012; Kramer, 2014; Jaszczak, Kristianova, 2019) on employment of green spaces with the view towards ecological (environmental), economic, social goals have revealed that green spaces should be accessible and used both by individuals and by the local community. Developing urban areas increase the threat of degradation of green spaces, and not only with the respect to nature and ecosystem services, as these developments also challenge how nature can support the wellbeing of various social groups. Growth of cities at the expense of nature contributes to degradation of nature, affecting not only natural ecosystems, but also people living in rural or urban areas (Kellert, 1995; Mell, 2010; Kemperman, Timmermans, 2014; Tiwari, 2018; Russo, Cirella, 2018). This approach linking green spaces (or natural green environment) and wellbeing have received considerable attention in both scientific and political discourse.

Copyright (C) 2020. Published by Vytautas Magnus University. This is an open access article distributed under the terms of the Creative Commons Attribution Non-Commercial 4.0 (CC BY-NC 4.0) license, which permits unrestricted use, distribution, and reproduction in any medium provided the original author and source are credited. The material cannot be used for commercial purposes. 
The target group of the article is the youth and enhancing their wellbeing through green spaces creates the prerequisite for formation of a strong, conscious, and responsible personality. In this respect, green spaces are turning into a great opportunity for the youth to satisfy their need for nature learning and cultivate the values of responsibility and volunteering (Bourke, Geldens, 2007; Simovska, 2012; Capaldi et al., 2015). For the youth, green spaces are the places for education, environmental consciousness and values, nature learning skills, health improvement, promotion and strengthening of their integration and participation in local community through various activities (Galloway et al., 2006; Cutter-MacKenzie, 2009; Artmann et al., 2017; Belmeziti et al., 2018).

In the recent decade, improvement of wellbeing through green spaces for different social groups has been emphasized as an important question in many foreign studies (Simovska, 2012; Capaldi et al., 2015; Tiwari, 2018). Nonetheless, it has received less attention in Lithuanian scientific and political reports and practical studies. There is an increased interest in wellbeing research considering various domains of life or factors which influence wellbeing and its outcomes (Bourke, Geldens, 2007; Kemperman, Timmermans, 2014). The role of green spaces and, in particular, its social benefit for improvement of young people's wellbeing is viewed fairly narrowly and insufficiently in the Lithuanian social sciences, and various researchers have been attempting to deal with this issue using different theoretical approaches, interdisciplinary fields, and adopting specific methods. There are various factors which influence a person's wellbeing, including both internal (personal, subjective) and external (objective) factors of a living place. The topic of relation/influence of green spaces to/on youth wellbeing is fairly new in the social sciences in Lithuania, in particular, when applied to a particular social group. Furthermore, this paper has sought to bridge the knowledge gap in Lithuanian social sciences by identifying the interface between green spaces and youth wellbeing, and how these connections can inform interested actors to achieve positive outcomes promoting youth wellbeing. This small-town case study can be relevant in an international debates as well by highlighting the importance of youth in the context of other social groups especially in the local level. This Lithuanian case supplement the knowledge about ways to analyse youth situation in local level, it can broaden the understanding of what they lack whether to have high level of wellbeing concerning green spaces. Various researchers and statistics show that young people in Lithuania tend to change their place of residence to larger cities or abroad, leaving rural areas or small towns. Nonadapted green spaces for youth is one of the factors that limits their self-expression, activities, communication and environmental awareness. This case study can be one of the examples how experts interview can contribute to exploring the youth wellbeing situation which reflects to situation and development of green spaces.

In line with the discussion mentioned above, the research object is green spaces as factor of youth wellbeing. The aim of this article is to explore the importance of green spaces to youth wellbeing. The research aim has been developed according to and is supported by the research question: in which ways can green spaces contribute to better wellbeing of youth? The research objectives: 1) theoretically to describe the benefit of green spaces to youth, 2) to prepare the research methodology, 3) to reveal the results of the research.

Research methods. The type of this research is both descriptive and empirical. The descriptive approach is implemented by characterising the green spaces in the analysed town to identify their potential for various activities of the youth, and the green spaces that are not always used for social purposes. Analysis of the benefit of green spaces for young people's wellbeing in Lithuania is significant not only for this case, but also could be applicable to other local areas in Lithuania. Empirical part of research involves experts' (people who work with young people) semi-structured interviews in different fields. The aim of the experts' semi-structured interviews is to analyse the importance of green spaces for improving you people's wellbeing (people aged 14-29 in Lithuania are described as young people (Jaunimo politikos..., 2018). The interview protocol has been designed using 17 questions grouped into three question blocks: 1) the experts' characteristics have been identified, 2) statements and questions about green spaces have been provided, and 3) the experts have evaluated how green spaces influence the youth wellbeing. The third group of questions is the 
most significant because it has enabled to identify the interface between green spaces and youth wellbeing. Accordingly, the result part contains several selected questions, which disclose the essence of the research most clearly.

12 experts have been enrolled in the interview. Experts' selection criteria are as follows:

- activity/interests are close to nature/environment and young people's personal development;

- the persons are enrolled directly and quite often in the interaction with local community (mainly working with the youth);

- they work with different social groups of young people in the community.

The experts have explored their knowledge and opinion on how green spaces influence youth wellbeing in general, the links between green spaces and health, learning process, cognition of nature, inclusion and participation in various activities, relations with friends, emotional status and social skills. Furthermore, the experts have identified the green spaces which are the most useful to the youth and have shared their ideas about who and how could be responsible for promotion of youth activities in green spaces. The informants have been introduced to the aim of interview, their possible contribution to the research findings. Time and place was arranged with the informants, but most of the interviews were conducted at their work spaces.

In line with the rules of research ethics, all the experts were coded with letter "I" (like informant) and numbers - e.g. I1, I2, I3. This has secured their confidentiality in the analysis of results.

Criteria for town selection. The selected territorial unit for this research is one suburban town - Kuršènai, located in Šiauliai district municipality. The town is not the municipality centre. Šiauliai is one of Lithuania's largest towns, so urbanisation also influences the surrounding towns (such as Kuršènai). In small towns/villages of Lithuania we have more green spaces than in big towns and very often the usage and importance of these spaces is not evaluated properly. Accordingly the reasons to choose Kuršènai for the case study were:

- town near a city (but it can be rural area as well);

- number of residents;

- variety of green spaces (developed and natural);

- various groups of young people (teenagers, young families etc.) are present.

In the subsequent part of the article, the research results and insights are presented in relation to the future of youth wellbeing and the influence of green spaces on it.

\section{Results} wellbeing

2.1. Theoretical conceptualisation of the interface between green spaces and youth

The scientific literature based on this topic has enabled the authors to conclude that there are a lot of individual research studies dedicated specifically to either wellbeing or green spaces. The interrelation between wellbeing and green spaces is discussed less often and, notably, not covering any particular social group in Lithuania. This observation can be supported by some selected examples from previous Lithuanian scentific works where were analysed green spaces various approaches in local level. Tamosiunas et al. (2014) explored the results about the accessibility and use of urban green spaces, and cardiovascular health among Kaunas city population. The article support the idea that health dimension is one of the most used criteria which is analysed in the green spaces context. Abromas et al. (2015) made analysis on the current state of the Kretinga town square's recreational-architectural environment, were such problems were identified: the functional use of the square, existing car parking area in the central part of the square, the multifunctionaluse of the square. They pointed out that town square is a place where people could gather and the quality of the urban environment has a huge impact on people's lives. Kamičaitytė-Virbašienė and Vitkuvienè (2015) revealed their insights about reconstructed public spaces of Marijampole town center in the context 
of dimensions of sustainable development. They followed such evaluation criteria and found out that character and distinctiveness, connectivity and accessibility, social integration, adaptability, inclusiveness/multifunctionality, central places, sunny places and shadow are fully satisfied and used by local people. However the criteria of ecological balance, biodiversity, and definition and enclosure are not fully met because of various reasons. So here they notice just some elements which influence people wellbeing - connectivity and accessibility, social integration, adaptability, inclusiveness - but do not demonstrate interface with any social group. Liebuvienè and Šileikienè (2017) explored youth attitude to healthy and sustainable environment in Klaipeda town though it was not directly related to green spaces topic. They emphasized that there is need to encourage youth interest in the environment, to increase their environmental awareness, through various means and forms to look for solutions to improve the environment in which they live, study, work and rest. Such promotion of environmental consciousness can contribute to make efforts to live more sustainably. Jancius et al. (2018) analysed impact of ecologic education and values on pupils' ecologic consciousness in Kaunas city. The obtained results on the influence of formation of the environmental values allowed assuming that external factors (friends, family and school) are of great importance for the pupils' environmental consciousness, their environmental orientation of values and life priorities. Bernat et al. (2018) investigated the impact of visiting urban green spaces on wellbeing of residents in Lithuania. They found out that the residents of Lithuania visited urban green spaces irregularly, visits to green spaces depend on the season and explored ambiguous notice that those respondents who evaluated their wellbeing more negatively, tended to visit urban green spaces more often. It should be pointed out that mentioned publications had more focus on general importance of green spaces to local people and their wellbeing (do not giving attention is it big or small town), their health or revealing green spaces perceptions in social economic context, but not emphasizing its importance to youth. Although it is recognized that young people are an important part of the local community, the importance of green spaces for their wellbeing is hardly studied either from a subjective point of view or through expert interviews. So the novelty of this article lies in that the authors tend to specify this relation by identifying the target group of this research - youth.

Different researchers (Felce, Perry, 1995; Mensah et al., 2016) have noted that wellbeing as an important condition of any human life is influenced by dynamic interaction between objective life conditions, subjective feelings of wellbeing, and personal values and aspirations. In accordance to this, green spaces can be viewed as the objective life conditions which influence everybody's life, as we experience it every day, and the environmental values are developed throughout the human life. The interest in wellbeing of different social groups is increasing, as every case needs specific wellbeing evaluation methods, measures, and promotion implements. In sociology, wellbeing of different social groups is not analysed comprehensively enough (Bourke, Geldens, 2007; Veenhoven, 2008), but more attention is drawn on the factors which influence the level of feeling, being and behaving well.

In terms of the objects assumed when referring to green spaces, the scientific discourse refers to various objects (Kellert, 1995; Mell, 2010; The Multifuncionality..., 2012; Natural..., 2014; Russo, Cirella, 2018): open countryside, parks, waterways, gardens, streets, green corridors, garden squares, shared yards, school yards, community forests, woodlands, walking trails, natural monuments, playgrounds, architectural structures, allotments, etc. This variety of green spaces is also understood as features/characteristics usually typical of green spaces. It is worth noting that, in scientific literature, green spaces (Benedict, McMahon, 2006; Kemperman, Timmermans, 2014; Tiwari, 2018) are also referred to as the environmental infrastructure, natural spaces, public space/open space related to humans' daily life, outdoor space, social green surrounding/background, natural/man-made nature elements etc. Considering the above green space elements, it is obvious that they not only shape the living environment, promote cultivation of the surrounding nature, but also demonstrate the goods and services which could be generated from the green spaces. This shows that the usage of concept green space can be adopted to different scientific approaches and different practical cases depending on what the researcher analyses. 
Various international researchers emphasize that green spaces influence different domains of youth wellbeing. Scholars indicate multiple benefits of usage of green spaces in terms of young people's wellbeing such as:

- enhancement of overall wellbeing (Galloway et al., 2006; Mwendwa, Giliba, 2012; Kemperman, Timmermans, 2014; Belmeziti et al., 2018);

- health improvement (Mwendwa, Giliba, 2012; Artmann et al., 2017);

- reduction of stress and negative emotions (Fan et al., 2011; Mensah et al., 2016);

- enhancement of social interaction (Kemperman, Timmermans, 2014; Artmann et al., 2017);

- education through cognition of nature (Cornell et al., 2001; Artmann et al., 2017);

- promotion of physical activity (Fan et al., 2011; Tiwari, 2018);

- stimulation of social inclusion (Cutter-MacKenzie, 2009; Belmeziti et al., 2018);

- attractiveness of living area (Gupta et al., 2012; Cilliers, Timmermans, 2014);

- responsibility to the environment (Kramer, 2014; Van der Jagt, 2018).

Summarizing the researchers disclose various aspects of the importance of the green spaces in youth life, daily routine and activities. Some of them emphasize the overall wellbeing, others point concrete wellbeing domains related to social, educational, cognition, inclusion, environmental etc. aspects. It refers to both public and private open spaces in urban / rural areas, mostly covered by natural greenery, which are directly (active or passive recreation) or indirectly (positive influence on the urban environment) should be available to a variety of local people. These differing perspectives illustrate that the characteristics of green space are usually multidimensional and differ in their levels, but their ultimate function is still to satisfy humans' (including the youth) needs at the place they live and to ensure access to the benefits provided by the green spaces. It is important to be able to adequately differentiate between the rural versus urban green spaces and use them appropriately, as they differ in their purpose, functions and scope of use. Based on the emphasized approaches to youth wellbeing, the authors further present the findings of the exploratory research.

\subsection{Case study: green spaces characteristics of Kuršènai town}

The town chosen for the case study is full of green spaces (or natural nature, public spaces) which, according to various researcher mentioned above, very often are not perceived properly in the social context. Comparing the green spaces characterised on the theoretical level versus actual green spaces in the selected town of Kuršènai, it could be noted that the latter cover/surround a big part of the town. The analysed territory includes two elderships/wards (Kuršènai rural and urban elderships/wards), and the urban eldership/ward is surrounded with green spaces of the rural one (Fig. $1)$.

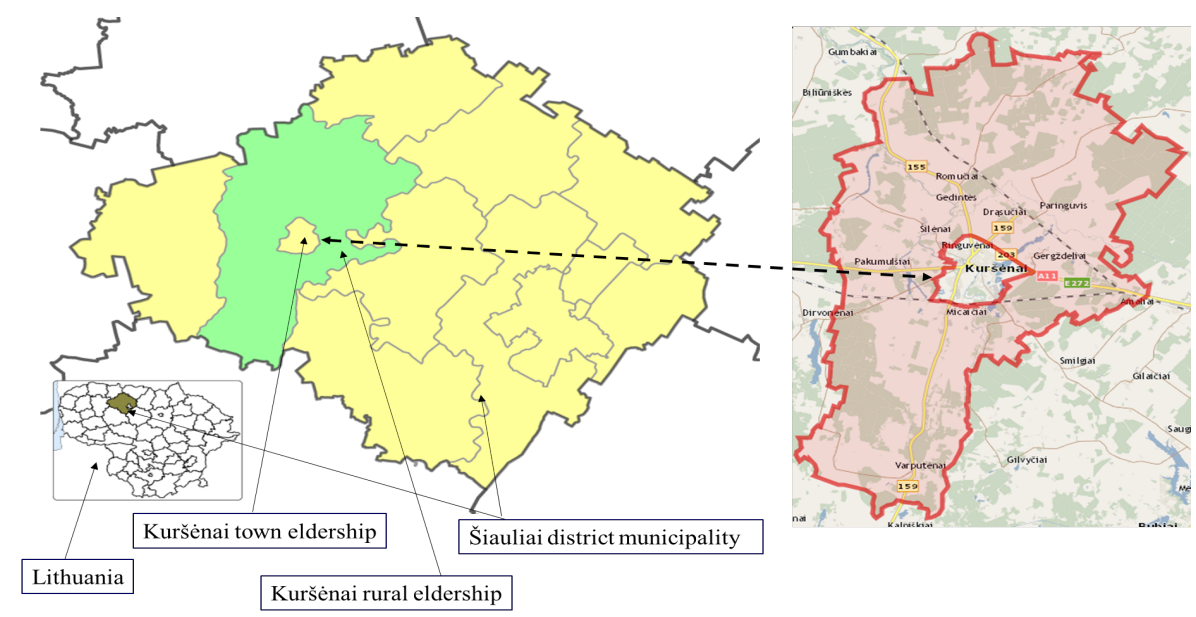

Figure 1. Maps of Kuršėnai town and general view in the context of Lithuania 
The list of green spaces is comprehensive: riverside nearby the river Venta, forests, quarry beach and camp, pinewood, parks, gardens, shared yards, school yards and parks, play/sport grounds, green streets, meadows, stadium, etc. (Table 1). It has been noticed that, although the research territory is full of green spaces, they are used insufficiently for the purposes of local community and, in particular, the youth. They mostly function as nature, but not really as an environment for cultivation of wellbeing.

The photos presented above showcase the changes taking place in the green spaces, with some of them being adapted to human activities, leisure. It should be noted that the activities depend on the level of development of the green spaces and of their influence. Hence, the respective type of green spaces indicates which green spaces are the most useful and most actively used (urbanized, in a certain sense), and which of them are used passively. Although there is a fairly large number of urbanised, man-influenced green spaces, the underdeveloped or natural spaces are and always will be attractive to humans.

Table 1. Examples of selected types of green spaces in Kuršènai town

\begin{tabular}{|l|l|ll|}
\hline \multicolumn{1}{|c|}{$\begin{array}{c}\text { Type of } \\
\text { green space }\end{array}$} & \multicolumn{1}{|c|}{ Explanation } & \multicolumn{2}{c|}{ Photo examples } \\
\hline $\begin{array}{l}1 \text { group - } \\
\text { Underdevelo } \\
\text { ped /natural } \\
\text { green spaces }\end{array}$ & $\begin{array}{l}\text { Spaces which are not } \\
\text { influenced by man; it is like } \\
\text { natural greenery, nature }\end{array}$ & Riverside by the river Venta & Forest paths \\
\hline $\begin{array}{l}2 \text { group - } \\
\text { Developing } \\
\text { green spaces }\end{array}$ & $\begin{array}{l}\text { Spaces semi influenced by } \\
\text { man; buildings surrounded } \\
\text { with the green space that is } \\
\text { suitable for young people's } \\
\text { activities }\end{array}$ & Downhill surrounding sport centre & Playground \\
\hline $\begin{array}{l}\text { Newly } \\
\text { developed } \\
\text { green spaces }\end{array}$ & $\begin{array}{l}\text { Manmade/influenced green } \\
\text { spaces }\end{array}$ & Book house in a park & \\
\hline
\end{tabular}

Source: photos made by the authors

The photos according to the selected green spaces presented in the table were selected at random. Each photo group reflects the different state of green spaces, which can have a corresponding effect on the well-being of young people, as full-fledged activities are available everywhere. According to the first group, although wildlife is often a great opportunity for various activities with young people, young people of different age groups will not necessarily have something to do there. On the other hand, such an environment encourages creativity, creates opportunities to strengthen 
physical and mental health. Spaces semi influenced by man suggest that existing restrictions on access to public green space can lead to a variety of actions, both positive (e.g. encouraging young people to enjoy future changes, a more beautiful, marketable environment ) and negative (e.g. wanting to try new facilities, which can lead to breakdowns etc.). In this situation, the person's choices are important - how to behave when we can influence the environment around us. The third photo group shows a ready-to-use green environment, where all that remains is to take advantage of the public goods created. Here, it is important to remind young people that what others have created for their wellbeing (beautifying the environment, creating an innovative space for action) should be their responsibility to preserve and maintain. Green transformations of spaces, their "overcoming" are related not only to the more convenient use of public spaces, but also to the idea that nature can be interesting to young people in many ways and serve in various forms.

Although Kuršènai surroundings feature diverse green spaces. It should be noted that various events, concerts, performances by schoolchildren, most often, take place at certain spots only: Town Park, Daugèliu pinewood, riverside of the river Venta, sportsgrounds and green spaces set up by the school. The more recent space is an outdoor class, for example, by Kuršènai Daugèlių lower secondary school. This signifies that the local community and the youth are accustomed to the existing green spaces which are used successfully, they are known to everyone and fairly easy to access; however, if viewed from the perspective of the youth, it would be reasonable to use the nature in a more diverse way in order to enhance own identity as that of the local resident, and to implement the place-based approach. According to Capaldi et al. (2015) and Mensah et al. (2016), identifying oneself with the local community and living environment of the place a young person lives in enhances his/her self-esteem, the sense of security and belonging to the area, which is the factor of their wellbeing. From the perspective of a potential effect of green spaces on youth wellbeing, it can be assumed that the green spaces provide the following benefits (Table 2).

Table 2. The benefits and effects of green spaces in relation to youth wellbeing (made by authors following Mwendwa, Giliba, 2012; Hunter, Luck, 2015; Liebuvienè, Šileikienè, 2017; Jancius et al., 2018; Russo, Cirella, 2018; Jaszczak, Kristianova, 2019)

\begin{tabular}{|l|l|}
\hline \multicolumn{1}{|c|}{ Benefit } & \multicolumn{1}{|c|}{ Effect } \\
\hline $\begin{array}{l}\text { - The youth is secured with the right to contribute to } \\
\text { beautification and preservation of the living } \\
\text { environment. }\end{array}$ & $\begin{array}{l}\text { The sense of aesthetic and the feeling of place } \\
\text { attachment are cultivated. }\end{array}$ \\
\hline $\begin{array}{l}\text { - The sense of responsibility to the local community is } \\
\text { cultivated. }\end{array}$ & $\begin{array}{l}\text { Personality is enhanced by cultivation of the sense } \\
\text { of responsibility and commitments, promotion of } \\
\text { social values. }\end{array}$ \\
\hline $\begin{array}{l}\text { - The youth is enabled to directly act and make influence } \\
\text { on preservation of the local natural resources. }\end{array}$ & Commitments, love to nature are enhanced. \\
\hline $\begin{array}{l}\text { - Young people of different social economic statuses (for } \\
\text { example, children from risk families, young people are } \\
\text { engaged in a joint activity together with their peers) are } \\
\text { brought together for a joint activity. }\end{array}$ & $\begin{array}{l}\text { Empathy to people who are different is promoted } \\
\text { when being and acting in nature. }\end{array}$ \\
\hline $\begin{array}{l}\text { - The role of Self among the peers and in the local } \\
\text { community becomes stronger (for example, "I can help } \\
\text { too", "I can do the same work as you do"). }\end{array}$ & $\begin{array}{l}\text { Strengthening of self-esteem by being in peer } \\
\text { groups and others }\end{array}$ \\
\hline - Promotion of civic consciousness & Strengthening of perception \\
\hline - Strengthening of the idea of volunteerism & $\begin{array}{l}\text { Development of understanding of the diversity of } \\
\text { activities (providing more than just a material } \\
\text { benefit) }\end{array}$ \\
\hline
\end{tabular}

In general, it could be claimed that young people's awareness, education and their environmental consciousness are the prerequisites for active participation in the community and moving towards greater wellbeing. Young people's commitments related to nature preservation, use 
of natural resources, formation of a healthier lifestyle, the skills of communication and cooperation are developed through implementation of diverse activities in green spaces and through the developed relationship with the environment. Accordingly, the perception of benefit of green spaces in the context of wellbeing can provide new forms of youth social interaction with various actors (teachers, peer-groups, parents, risk groups etc.), challenge their understanding about how important the nature surrounding their living environment is.

\subsection{Results of the experts' interview}

The experts' characteristics in relation to their participation in the interview have enabled the authors to notice their specific attitude towards the issue analysed. Table 3 demonstrates that the experts represent several professional fields and have different background in activities with the youth; nonetheless, they all share the experience and skills of working with various groups of youth. It could be claimed that viewing the issue analyzed from the perspectives of different professions has generated a more comprehensive picture of the opportunities to develop youth activities in green spaces and the benefits of green spaces to the local youth as seen by the experts.

Table 3. Characteristics of the experts involved in the interview

\begin{tabular}{|c|c|c|c|c|c|}
\hline $\begin{array}{l}\text { Characteristics } \\
\text { Specialist } \\
\text { code }\end{array}$ & $\begin{array}{l}\text { Gender } \\
(\mathrm{N}=12)\end{array}$ & $\begin{array}{c}\text { Age } \\
(\min =27 \\
\max =62)\end{array}$ & $\begin{array}{l}\text { Current work } \\
\text { position }\end{array}$ & $\begin{array}{l}\text { Experience } \\
\text { (in years) } \\
\text { working with } \\
\text { youth }\end{array}$ & Type of work with youth \\
\hline $\mathrm{I} 1$ & Woman & 62 & Head of library & 40 & $\begin{array}{l}\text { Organising of projects and } \\
\text { educational events }\end{array}$ \\
\hline $\mathrm{I} 2$ & Woman & 27 & Librarian & 2 & Club \\
\hline $\mathrm{I} 3$ & Woman & 33 & $\begin{array}{l}\text { Director, head } \\
\text { of young } \\
\text { parents } \\
\text { community } \\
\text { association }\end{array}$ & - & $\begin{array}{l}\text { Organising of projects and } \\
\text { events }\end{array}$ \\
\hline I4 & Woman & 30 & Teacher & 7 & Organising of events at school \\
\hline I5 & Woman & 57 & Librarian & 30 & $\begin{array}{l}\text { Organising games and } \\
\text { activities related to educational } \\
\text { purposes }\end{array}$ \\
\hline I6 & Woman & 56 & Teacher & 30 & $\begin{array}{l}\text { Organising summer camps, } \\
\text { working with projects related } \\
\text { to nature }\end{array}$ \\
\hline I7 & Woman & 50 & Social educator & 27 & $\begin{array}{l}\text { Preparation and } \\
\text { implementation of projects } \\
\text { (related to health, nature etc.) } \\
\text { and actions }\end{array}$ \\
\hline I8 & Woman & 40 & $\begin{array}{l}\text { Specialist for } \\
\text { the career } \\
\text { development }\end{array}$ & 8 & $\begin{array}{l}\text { Professional informing and } \\
\text { consulting }\end{array}$ \\
\hline I9 & Woman & 44 & $\begin{array}{l}\text { Teacher of } \\
\text { profession } \\
\text { (apiculture) }\end{array}$ & 8 & $\begin{array}{l}\text { Environment cognition and } \\
\text { protection activities, education } \\
\text { and practical usage of } \\
\text { apiculture }\end{array}$ \\
\hline I10 & Woman & 49 & $\begin{array}{l}\text { Health-care } \\
\text { specialist }\end{array}$ & 23 & $\begin{array}{l}\text { Strengthening of health, } \\
\text { development of personal skills, } \\
\text { prevention of harmful habits }\end{array}$ \\
\hline I11 & Men & 57 & $\begin{array}{l}\text { Forester - } \\
\text { engineer }\end{array}$ & 5 & $\begin{array}{l}\text { Co-ordination of activities of } \\
\text { young people, lectures, } \\
\text { cognitive education, }\end{array}$ \\
\hline
\end{tabular}




\begin{tabular}{|l|l|l|l|l|l|}
\hline & & & & $\begin{array}{l}\text { organization of bird nests } \\
\text { implementation festivals, } \\
\text { organization of competitions }\end{array}$ \\
\hline I12 & Men & 59 & $\begin{array}{l}\text { Basketball } \\
\text { coach }\end{array}$ & 30 & $\begin{array}{l}\text { Basketball training activities } \\
\text { inside and outside, } \\
\text { participation in various youth } \\
\text { related events, organisation of } \\
\text { district and republic } \\
\text { competitions and camps, } \\
\text { sports education, health } \\
\text { promotion activities }\end{array}$ \\
\hline
\end{tabular}

Before starting the interview, the current situation of green spaces was discussed with the experts. It is worth noting that their perception about the kinds of green spaces that are important to local community was almost the same. Differences appeared when they emphasized what kind of green spaces were the most important to particular social groups. According to the experts' general approach, the following aspects were highlighted:

- the importance of green spaces is not really recognised as a valuable aspect of wellbeing;

- young generation needs green spaces where they could have active time, but also for relaxation;

- the most significant problem referred to during all the interviews - absence of any new, modern, attractive green spaces in the described area;

- the problem is that green spaces are not appropriate for different age groups of youth (e.g. still teenagers or young families);

- the problem of using green spaces is typical for all social groups, not only youth.

The identified insights are further analysed by focusing on individual questions related to the research problem.

The following common findings were explored during the specialists' interview:

- green spaces are not developed enough to be able participate actively in the small town;

- wellbeing of youth does not depend only on them - it is a matter of various local actors and depends on how they are concerned;

- activities provided for the youth should be divided into different types of green spaces (parks, play yards, education area etc.) depending on the age group;

- youth participation in various activities in natural environment can strengthen their self-esteem, health, communication skills, they become more socialised - all of this influences their overall wellbeing;

- this type of research builds stronger understanding that more different methods, people, government representatives should be involved in the process of supporting local-rural youth.

Besides the similar observations on green spaces and their need and benefit to the youth expressed by the experts, the experts were also asked to name the key functions which are/could be performed by green spaces in the context of youth wellbeing in order to find out the experts' opinion about the existing green spaces in the selected case (Table 4). 
Gintarè Vaznonienè, Bernardas Vaznonis

Strengthening Youth Wellbeing through Green Spaces: Case Study of a Small Town

Table 4. Experts' opinion about functions which are implemented by (within) the existing green spaces

\begin{tabular}{|c|c|c|c|}
\hline Function & $\begin{array}{c}\text { Number of } \\
\text { answers }\end{array}$ & $\begin{array}{c}\text { How it influences } \\
\text { youth wellbeing }\end{array}$ & Examples of supporting ideas \\
\hline $\begin{array}{l}\text { - Activation of } \\
\text { rural youth }\end{array}$ & 7 & $\begin{array}{l}\text { By implementation of } \\
\text { various forms of leisure } \\
\text { activities }\end{array}$ & $\begin{array}{l}<\ldots \text { active leisure is important...> (I1) } \\
<\ldots \text { children can play various games...>(I8) }\end{array}$ \\
\hline - Sports activities & 5 & $\begin{array}{l}\text { Improvement of physical } \\
\text { and mental health, } \\
\text { leisure outside, outings, } \\
\text { etc. }\end{array}$ & $\begin{array}{l}<\ldots \text { these spaces encourage people to work } \\
\text { out...>(I4) } \\
<\ldots \text { physical training before competitions } \\
\text { is conducted here... }>\text { (I12) }\end{array}$ \\
\hline $\begin{array}{l}\text { - Communication/ } \\
\text { social interaction }\end{array}$ & 6 & $\begin{array}{l}\text { Being and socialising } \\
\text { with others }\end{array}$ & $\begin{array}{l}<\ldots \text { promote communication... }>(\text { I1 }) \\
<\ldots \text { young people spend time with their } \\
\text { friends... }>\text { (I7) }\end{array}$ \\
\hline $\begin{array}{l}\text { - Environmental } \\
\text { protection }\end{array}$ & 4 & $\begin{array}{l}\text { Improvement of the air, } \\
\text { cleaning of nature }\end{array}$ & $\begin{array}{l}<\ldots \text { improve air quality... }>(\text { I1 }) \\
<\ldots \text { clean the air, reduce the pollution, } \\
\text { absorb electromagnetic radiation... }>(\text { I9) }\end{array}$ \\
\hline $\begin{array}{l}\text { - Enhancing social } \\
\text { integration }\end{array}$ & 5 & $\begin{array}{l}\text { Strengthening family } \\
\text { relations (children with } \\
\text { parents), meetings of } \\
\text { young mums, meetings } \\
\text { of mixed youth groups }\end{array}$ & $\begin{array}{l}<\ldots \text { they can spend their leisure time with } \\
\text { their families and friends... }>\text { (I4) } \\
<\ldots \text { young mothers with their children can } \\
\text { spend their time in the parks... }>\text { (I7) }\end{array}$ \\
\hline $\begin{array}{l}\text { - Cognition of } \\
\text { nature }\end{array}$ & 2 & $\begin{array}{l}\text { Being acquainted with } \\
\text { fauna and flora }\end{array}$ & $\begin{array}{l}<\ldots \text { observation of nature and its cognition } \\
\text { develop thinking abilities... }>\text { (I5) } \\
<\ldots \text { educational cognitive activities can be } \\
\text { arranged... }>\text { (I9) }\end{array}$ \\
\hline $\begin{array}{l}\text { - Health } \\
\text { improvement } \\
\text { (both physical } \\
\text { and mental) }\end{array}$ & 5 & $\begin{array}{l}\text { Strengthen their health } \\
\text { and fill themselves with } \\
\text { positive emotions }\end{array}$ & $\begin{array}{l}<\ldots \text {.improve physical health and mental } \\
\text { wellbeing...>(I2) } \\
<\ldots \text { games, vigorous activity strengthen } \\
\text { health...>(I8) }\end{array}$ \\
\hline - Aesthetic & 4 & $\begin{array}{l}\text { Formation of public } \\
\text { spaces, local image } \\
\text { formation }\end{array}$ & $\begin{array}{l}<\ldots \text { make the environment more } \\
\text { beautiful...>(I4) } \\
<\ldots \text { make the environment more beautiful } \\
\text { and clean it... }>\text { (I10) }\end{array}$ \\
\hline $\begin{array}{l}- \text { Negative } \\
\text { approach }\end{array}$ & 1 & Not enough green spaces & $\begin{array}{l}<\ldots \text { it must be recognized that Kuršènai } \\
\text { lack proper green spaces, there are a lot of } \\
\text { broken swings, unattended places... }>\text { (I3) } \\
<\ldots \text { there is lack of play yards, sports } \\
\text { grounds for active engagement...>(I6) }\end{array}$ \\
\hline
\end{tabular}

The table suggests that the functions of green spaces identified by the experts and the relative benefit defined by them are fairly close to the ones which have been described in the research studies. Although the experts are fairly specific in their answers, it is obvious that positive benefits rather than negative effect of green spaces in relation to the youth are emphasized.

It should be noted that, when speaking about the youth, the research participants put a clear emphasis on the age group the young people belong to, for example, just the youth, children (when speaking about teenagers), young moms, etc.

Moreover, it can be noticed that, when referring to green spaces, certain participants mentioned that they were also causing negative associations, if there were no green spaces set up properly, or if they were posing threat to active engagement due to the old equipment. One of the experts (I8) noted that, depending on the situation and young people's condition during their outing in the nature, there is a risk of destructive behaviour, when young people drink alcohol in the forest, start fighting or breaking benches, even trees, i.e. harm the environment. 
It should be noted that the positive or destructive behaviour is related to the type of green space used, as it has been observed that the young people who are inclined towards a destructive behaviour more often tend to act this way in the green spaces still under construction or manmade green spaces. They are more likely to break, destroy certain equipment rather than harm the nature directly.

There is a number of factors related to green spaces which form youth wellbeing, and, in one of the questions, the experts were given several life domains related to youth wellbeing, which, according to various researchers, can also be influenced by green spaces (Table 5).

Table 5. Experts' opinion about how green spaces influence individual domains of youth wellbeing

\begin{tabular}{|c|c|c|c|}
\hline Health & Learning process & $\begin{array}{c}\text { Cognition of the } \\
\text { nature }\end{array}$ & $\begin{array}{c}\text { Inclusion and } \\
\text { participation in various } \\
\text { activities }\end{array}$ \\
\hline $\begin{array}{l}\text { - Improves breathing } \\
(3)^{*} \\
\text { - Improves behavior (3) } \\
\text { - Reduce stress (4) } \\
\text { - Controls weight (3) }\end{array}$ & $\begin{array}{l}\text { - Improves learning } \\
\text { outcomes (5) } \\
\text { - Learning from others } \\
\text { (3) } \\
\text { - Cultivate } \\
\text { imagination (3) }\end{array}$ & $\begin{array}{l}\text { - Natural way of } \\
\text { nature cognition (10) } \\
\text { - Challenges various } \\
\text { experience (5) } \\
\text { - Helps to feel the } \\
\text { beauty of nature (6) }\end{array}$ & $\begin{array}{l}\text { - Enhance the youth } \\
\text { activity (12) } \\
\text { - Forms friendly attitude to } \\
\text { others and nature (4) } \\
\text { - Self-realization becomes } \\
\text { easier by doing not only } \\
\text { observing (3) }\end{array}$ \\
\hline Self-evaluation & $\begin{array}{l}\text { Relations with } \\
\text { friends }\end{array}$ & & Social skills \\
\hline $\begin{array}{l}\text { - Strengthen self-esteem } \\
\text { ( } 7 \text { ) } \\
\text { - Elevates responsibility } \\
\text { (4) } \\
\text { - Youth can feel } \\
\text { important to others (5) }\end{array}$ & $\begin{array}{l}\text { - Becoming closer to } \\
\text { others (6) } \\
\text { - Cognition of } \\
\text { friends/fellows in } \\
\text { unusual spaces (6) } \\
\text { - Enhace cooperation } \\
\text { skills (4) }\end{array}$ & $\begin{array}{l}\text { - Becoming more } \\
\text { happy, positive (12) } \\
\text { - Reduce stress (7) } \\
\text { - Improves the mood } \\
\text { (6) }\end{array}$ & $\begin{array}{l}\text { - Learning from older } \\
\text { friends (2) } \\
\text { - Develops independence } \\
\text { (3) } \\
\text { - Responsibility, care of } \\
\text { others and nature (6) }\end{array}$ \\
\hline
\end{tabular}

*Note: the number of experts is given in brackets.

The presented table clearly shows that the majority of the experts have shared similar thoughts for many of the life domains. The opinion that green spaces contribute to cognitive education, which is related both to environmental and ecological consciousness, as well as enhancement of the youth activity and becoming happier and more positive, was shared by the experts the most (noted by 10 or 12 experts respectively.

This indicates that the experts who communicate with the youth directly can observe and register the changes in youth behaviour, mental health, emotions when being inside versus outdoor activities in green spaces, fairly well. Young people, in particular, teenagers, are still in the process of personality formation, and, by properly encouraging the youth to act, supporting or directing the youth towards targeted activities, experts may enhance many areas contributing to higher wellbeing of youth.

Self-esteem and awareness of where they can fulfil themselves are very important for young people of different age groups. Participation in social activities strengthen and develop young people in a number of different ways. Hence, the experts were asked how green spaces could enhance young people's social inclusion and participation by grouping them into smaller groups: teenagers and older youth (Table 6). 
Table 6. Experts' opinion about how green spaces enhance young people's social inclusion and participation

\begin{tabular}{|c|c|}
\hline Teenagers & Older youth groups \\
\hline $\begin{array}{l}\text { - Promoting sport activities (I1, I7, I8, I10) } \\
\text { - Creating more aesthetic environment (I1) } \\
\text { - Arranging teaching in unconventional spaces (“lessons without } \\
\text { walls") (I2, I7) } \\
\text { - Educational activities (environmental education) (I2, I9) } \\
\text { - Organizing summer camps (I2, I6) } \\
\text { - Excursions/trips for better cognition of the nature (I2, I7) } \\
\text { - Various events (I3, I4, I5) } \\
\text { - Promotion of volunteering (I3) } \\
\text { - Engagement in real work (I3) } \\
\text { - Games (I1, I5) } \\
\text { - Meeting prominent people (I8) }\end{array}$ & $\begin{array}{l}\text { - Working in nature (clearing the } \\
\text { nature)(I1) } \\
\text { - } \text { Events, festivals, actions (I2, I4, I5) } \\
\text { - Doing together, but not for them } \\
\text { (I3, I9) } \\
\text { - Promoting sports (I5) } \\
\text { - Doing projects (environmental, for } \\
\text { recreation) (I2, I6) } \\
\text { - Volunteering/altruistic activities } \\
\text { (I4, I7) } \\
\text { - Meeting prominent people (I8) }\end{array}$ \\
\hline
\end{tabular}

The results have shown that the experts had more ideas and, probably, practice working with younger groups, because it was much easier for them to give the details about how young people could become more socially engaged with green spaces. It has been observed that younger groups activities are well known, desired, but not always properly implemented due to inadequate equipment, lack of local community activities, or may even depend on the role (whether the young people are more passive or active).

For older youth, to the contrary, the identified forms of inclusion activities are more serious. Interesting to note is that the experts' speeches highlight more general and interesting facts, revealing how green spaces enhance social inclusion and participation of older young people:

- doing / working together, but not instead of the youth, is important in the nature;

- arranging various activities is important to the youth, but many questions arise: Who? When? For what purpose? How are we doing this?

- unclear actual actions - how to do this (lack of initiatives from the youth);

- older youth wellbeing and inclusion is related to more serious activities (comparing to younger youth activities) directing towards the volunteering work, work, civic consciousness.

The whole analysis has enhanced the level of knowledge about the ways that green spaces could contribute to better wellbeing of youth. It should be pointed out that the importance of young people's inclusion and engagement in cultivation of green spaces and greater life wellbeing manifest themselves through the following effects created:

- The youth is secured with the right to contribute to beautification and preservation of the living environment.

- The sense of responsibility to the local community is cultivated.

- The youth is enabled to directly act and make influence on preservation of the local natural resources.

- Young people of different social economic statuses (for example, children from risk families, young people are engaged in a joint activity together with their peers) are brought together for a joint activity.

- The role of Self among the peers and in the local community becomes stronger (for example, "I can help too", "I can do the same work as you do").

- Civic consciousness is promoted.

- The idea of volunteering is strengthened.

All the above mentioned experts explored diverse, but, in most cases, related attitudes towards the functions, benefit and influence of green spaces on youth wellbeing in the analysed case. The greatest positive aspect is that Kuršėnai town (including rural and urban elderships/wards) has a large number of open green spaces, which still lack attention to be suitable for proper use by the locals. It 
should also be pointed out that social interaction, inclusion of youth through community activities in green spaces have different benefits for their personal self-esteem and social respect, mental health and physical behaviour. Finally, it is worth noting, on the basis of the experts' insights, that social connectedness put to practice in green spaces enables young people to develop the sense of belonging and good interpersonal relationships with others - all of this supports their social wellbeing, which is one of the most influential domains of their overall wellbeing.

\section{Conclusions}

As it was identified from the literature review green spaces, their functions and possible effects can be a positive stimulator to promote greater wellbeing on various social groups' life domains. International scientific discussion on this topic is developing, but the problem of green spaces importance to youth wellbeing in small town is still limited.

Although the concept of green spaces and the benefits provided by them is multidimensional, their social benefit for the youth (and the whole local community) has been recognized increasingly, as green spaces not only create the relationship between the human and the nature, but also help support interaction between people. Green spaces of different types or levels of development in small town contribute to cultivation of a young person's consciousness about proper behaviour in the nature.

The experts' interview has revealed that promotion of youth integration and engagement and maintaining a certain level of wellbeing by using green spaces is a great opportunity for the youth to fulfil themselves, strengthen own Self, feel themselves needed by the local community, gain new skills and experience. Perception of oneself as of a part of the nature also enhances the sense of identity in relation to the living place, also it can attract and retain youth to stay where they live and not to move to bigger towns.

Though the experts' interview was the one-sided evaluation of how green spaces can affect youth, their insights, observations and considerations enable to think/identify how various local actors can be responsible for enhancing the youth to take chance to act in green places.

The study has determined that green spaces provide considerable social benefit to both the youth and the local community. Participation of the youth in various activities in green spaces enhances their values, expands the field of knowledge about the natural environment, cultivates healthy lifestyle attitude, contributes to positive socialization not only in the local community, but in the society as well.

\section{References}

Abromas, J., Grecevičius, P., Marčius R., Piekienè, N. (2015). Complex Studies of Kretinga Town Hall Square andDevelopment Possibilities. Formation of Urban Green Areas, 1(12): 8-13.

Artmann, M., Olaf, B., Karsten, G. (2017). "Using the Concepts of Green Infrastructure and Ecosystem Services to Specify Leitbilder for Compact and Green Cities-The Example of the Landscape Plan of Dresden (Germany)." Sustainability 9(2):198.

Belmeziti A., Frédéric, Ch., Kaufmann, B. (2018). „Improving the multi-functionality of urban green spaces: Relations between components of green spaces and urban services“. Sustainable Cities and Society, (43): 1-10.

Benedict, M. A., McMahon, E. (2006). Green infrastructure: Linking landscapes and communities. Washington, DC: Island Press.

Bernat A., Marozas, V., Žalkauskas, R. (2018). Investigation of the impact of visiting urban green spaces on wellbeing of residents. Žemès ükio mokslai. T. 25 (2): 81-90.

Bourke, L., Geldens, P. M. (2007). "Subjective wellbeing and its meaning for young people in a rural Australian centre". Social Indicators Research, 82 (1): 165-187.

Capaldi, C. A., Passmore, H.A., Nisbet, E. K., Zelenski, J.M., Dopko, R. L. (2015). "Flourishing in nature: A review of the benefits of connecting with nature and its application as a wellbeing intervention" // International Journal of Wellbeing, 5(4): 1-16. 
Cilliers, E. J., Timmermans, W. (2014). "The importance of creative participatory planning in the public place-making process". // Environment and Planning B: Planning and Design, (41): 413 - 429.

Cornell, E. H., Hadley, D. C., Sterling, T. M., Chan, M. A., Boechler, P. (2001). "Adventure as stimulus for cognitive development". // Journal of Environmental Psychology (21): 219-231.

Cutter-M., A. (2009). "Multicultural school gardens". // Canadian Journal of Environmental Education (14): 122-35.

Fan, Y., Das, K. V., Chen, Q. (2011). "Neighborhood green, special support, physical activity and stress: Assessing the cumulative impact". // Health \& Place (17): 1202-1211.

Felce, D., Perry, J. (1995). "Quality of life: Its definition and measurement". // Research in Developmental Disabilities 16(1): 51-74.

Galloway, S., Bell, D., Hamilton, C., Scullion, A.C. (2006). Well-Being and Quality of Life: Measuring the Benefits of Culture and Sport - A Literature Review and Thinkpiece. Series: Education (Scotland. Social Research). Scottish Government: Edinburgh, UK.

Green infrastructure and territorial cohesion. (2011). "The concept of green infrastructure and its integration into policies using monitoring systems". EEA Technical report. European Environment Agency. http://www.greeninfranet.org/uploads/documents/EEA\%20Green\%20infrastructure_Territorial\%20cohesion. pdf [20 012019$]$

Gupta, K., Pramod, K., Pathan, S. K., Sharma, K. P. (2012). "Urban neighborhood green index - A measure of green spaces in urban areas". // Landscape and Urban Planning (105): 325-335.

Hunter, A.J., Luck, G.W. (2015). Defining and measuring the social-ecological quality of urban greenspace: A semi-systematic review. Urban Ecosyst. 2015, 18, 1139-1163.

Jancius, R., Vaznoniene, G., Gavenauskas, A., Pekarskas, J. (2018). Impact of ecologic education and values on pupils' ecologic consciousness. // New Trends and Issues Proceedings on Humanities and Social Sciences. 5(5): 49-59.

Jaszczak A., Kristianova K. (2019). Social and Cultural Role of Greenery in Development of Cittaslow Towns "World Multidisciplinary Civil Engineering-Architecture-Urban Planning Symposium - WMCAUS 2019", IOP Publishing Conference Series: Materials Science and Engineering. doi:10.1088/1757899X/603/3/032028

Jaunimo politikos pagrindų įstatymo Nr. IX-1871 pakeitimo įstatymas (Youth Policy Framework Law Nr. Amendment Act IX-1871). 2018 m. gegužès 31 d. Nr. XIII-1224, Vilnius, Lietuvos Respublikos Seimas.

Kamičaitytė-Virbašienè, J., Vitkuvienė, J. (2015). Reconstructed Public Spaces of Marijampolè Center in the Context of Dimensions of Sustainable Development. // Formation of Urban Green Areas. 1(12): 151167.

Kellert, S. R. 1995. The biological basis for human values of nature. In Kellert S. R., Wilson, E. O. (eds.) The Biophilia Hypothesis. Island Press, Washington, 496 p., p. 42-72, 1995.

Kemperman, A., Timmermans, H. (2014). "Green spaces in the direct living environment and social contacts of the aging population". // Landscape and Urban Planning (129): 44-54.

Kramer, M. G. (2014). Enhancing sustainable communities with green infrastructure. A guide to help communities better manage stormwater while achieving other environmental, public health, social, and economic benefits. U.S. Environmental Protection Agency's Office of Sustainable Communities. EPA 100-R14-006. - https://www.epa.gov/sites/production/files/2014-10/documents/green-infrastructure.pdf [ [ $\begin{array}{ll}10 & 09\end{array}$ 2018]

Liebuvienè, J., Šileikienè, A. (2017). Youth Attitude to Healthy and Sustainable Environment. // Formation of Urban Green Areas. 1(14):135-141.

Mell, I. C. (2010). Green infrastructure: concepts, perceptions and its use in spatial planning. Thesis submitted for the Degree of Doctor of Philosophy. School of Architecture, Planning and Landscape Newcastle University.

Mensah, C. A., Andres, L., P., Upuli, Roji, A. (2016). "Enhancing quality of life through the lens of green spaces: A systematic review approach". // International Journal of Wellbeing, 6(1): 142-163.

M'Ikiugu, M. M., Qianna, W., Kinoshita. I. (2012). "Green Infrastructure Gauge: A tool for evaluating green infrastructure inclusion in existing and future urban areas". // Procedia-Social and Behavioral Sciences (68): $815-825$.

Mwendwa, P., Giliba, R.A. (2012). Benefits and Challenges of Urban Green Spaces, // Chinese Journal of Population Resources and Environment (10):1, 73-79.

Natural Environment White Paper. (2014). Implementation update report. Department for Environment Food and Rural Affairs. 
https://www.gov.uk/government/uploads/system/uploads/attachment_data/file/286547/newpimplementation-update-20140226.pdf [06 02 2019]

Russo A., Cirella GT. (2018). Modern Compact Cities: How Much Greenery Do We Need? Int J Environ Res Public Health. 15 (10): 2180. doi:10.3390/ijerph15102180

Simovska, V. (2012). "What do health-promoting schools promote? Processes and outcomes in school health promotion". Health Education, Vol. (112)2: 84 - 88.

Tamosiunas, A., Grazuleviciene, R., Luksiene, D. et al. (2014). Accessibility and use of urban green spaces, and cardiovascular health: findings from a Kaunas cohort study. // Environ Health, 13(1): 20.

Tiwari, R. (2018). Connecting spaces, connecting people: a paradigm for urban living in the 21 st century. New York, NY: Routledge.

The Multifunctionality of Green Infrastructure. (2012). Science for Environment Policy. In-depth Reports. European Commission.

http://ec.europa.eu/environment/nature/ecosystems/docs/Green_Infrastructure.pdf [25 03 2019]

Van der Jagt, A.P.N. (2018). Co-creating urban green infrastructure connecting people and nature: A guiding framework and approach. // Journal of Environmental Management (233): 757-767.

Veenhoven, R. (2008). Sociological Theories of Subjective Well-Being. In: Michael Eid \& Randy Larsen (Eds). "The Science of Subjective Well-being: A tribute to Ed Diener", Guilford Publications, New York, 44-61. 